

\section{Shirkah}

Journal of Economics and Business

Vol. 2, No. 1, January-April 2017

ISSN: 2503-4235 (p); 2503-4243 (e)

\section{Editor in Chief}

Sri Walyoto

\section{Editorial Boards}

Abu Umar Faruq Ahmad, UBD School of Business and Economics, Brunei Darussalam

Amelia Fauzia,

Asia Research Institute, National University of Singapore, Singapore

Cedomir Nestorovic,

ESSEC Business School Asia Pacific, Singapore

Dwi Condro Triono,

Faculty of Islamic Economics and Business, IAIN Surakarta, Indonesia

Fahmy Radhi,

Faculty of Economics and Business Universitas Gadjah Mada, Yogyakarta,

Indonesia

Hasan Basri,

Syiah Kuala University, Aceh, Indonesia

Johan Fischer,

Department of Social Sciences and Business Roskilde University, Denmark

Masudul Alam Choudhury,

Postgraduate Program in Islamic Economics and Finance, Trisakti University,

Jakarta, Indonesia and the College of Economics and Political Science (CEPS) in

Sultan Qaboos University (SQU), Oman

M. Falik Isbah,

School of Humanities and Social Science, University of New South Wales, Australia M. Ishaq Bhatti,

La Trobe Business School Department of Economics and Finance La Trobe

University, Australia

Najib Kailani,

Pascasarjana, Universitas Islam Negeri (UIN) Sunan Kalijaga, Yogyakarta, Indonesia 
Nunung Nurul Hidayah,

Aston Business School, Aston University, Birmingham, United Kingdom

Shaikh M Ghazanfar,

Departement of Economics, University of Idaho, Russian Federation

\section{Managing Editors}

Fitri Wulandari

Jasanta Perangin-angin

\section{Assistant to Editor}

M. Endy Saputro

M. Zainal Anwar

Supriyanto

Shirkah Journal of Economics and Business is a peer-reviewed journal published three times a year (January-April, May-August and September-December) by Faculty of Islamic Economics and Business, Institut Agama Islam Negeri (IAIN/ State Institute for Islamic Studies) Surakarta Central Java, Indonesia. The main objective of Shirkah is to offer an academic space of exchange ideas and initiate the increase number of qualified article produced by postgraduate students, practitioners and academicians.

\section{Editorial Office}

Ruang Jurnal Shirkah

Ground Floor, West Gate,

Faculty of Islamic Economics and Business

IAIN Surakarta

Jln. Pandawa No. 1, Kartasura, Sukoharjo, Jawa Tengah Kode Pos. 57168

Phone (+62271) 781516 Fax: (+62271)782336

E-mail: shirkahiainsurakarta@gmail.com

Website: http://shirkah.or.id/ 



\section{Shirkah}

Journal of Economics and Business

Vol. 2, No. 1, January-April 2017

ISSN: 2503-4235 (p); 2503-4243 (e)

\section{Table of Contents}

\section{Articles}

Ana Zahrotun Nihayah

Savings and Loans Program, The Revenue of Small Micro Entreprises and Poverty Reduction among Women Groups

Ana Fadhilah

Muslimah Entrepreneurship and Economic Empowerment in Pengajian

Umiyati

Local Economics Empowerment and Sharia Microfinance in Rural

Community Perception

Lathif Hanarif Rifqi

Community Empowerment through Islamic Microfinances Perceptions in Comparison

Ahmad Lukman Nugraha

Islamic Business Ethics and Islamic Microfinance in Pesantren Gontor

Nova Ch. Mamuaya

Service Quality and Non-Muslim Satisfaction Using Sharia Bank Products and Services 



\title{
Local Economics Empowerment and Sharia Microfinance in Rural Community Perception
}

\author{
Umiyati \\ Universitas Islam Negeri Syarif Hidayatullah Jakarta \\ umiyati@uinjkt.ac.id
}

\begin{abstract}
This paper proposes to analyze and gain empirical evidences of the rural community perception on sharia micro finance institution to empower local economics at Margoyoso-Pati District Central Java, Indonesia. The data were gathered with survey method and questionnaire. The analysis technique in use is multiple linear regressions. The findings of the paper shows significant evidences on constructed research hypothesis, namely the products of Sharia Micro Finance Institution and the its services affecting the rural community perception on the sharia one, whereas on parametrically ( $\mathrm{t}$ statistic test) and simultaneous (F statistic test). It shows better rural community knowledge and understanding on offered products from the Sharia Micro Finance Institution and their services quality; the two variables will simultaneously and parametrically affect rural community perception on Sharia Micro Finance Institution to empower local economics.
\end{abstract}

Keywords: economic empowerment, service quality, rural community perception, Sharia Micro Finance

\section{Introduction}

Baitul Maal wa Tamwil (BMT) phenomenon and sharia cooperation is part of the Sharia Micro Finance Institution (LKMS) model. Both institutions provide service for low to middle level people, namely micro (small) scale financing. The BMT problem at the moment is legality. The reality shows BMT existence legality does not have clear legal protection. Expected BMT legal protection, LKMS law plan is not 
yet clear. While the Sharia Micro Finance Institution law legalizes, BMT existence could be included in the LKMS law.

The condition shown above shows BMT is not considered as illegal financial institution due to the Law No. 251992 on cooperation. Several BMT has operated with legalization of cooperation law, namely registering the operation to Cooperation Office and UKM at Regency and municipality level. The Law No. 251992 on cooperation does not consist of sharia aspect comprehensively, operationally or financing model, observation system, competency standard, risk management, and other LKMS related matters which strongly different from conventional saving and loan cooperation. One might say cooperation is "the cloth" and BMT is "the body."

On April 22 $2^{\text {nd }} 2010$, on Republika Online (ROL), BMT Modal CEO, Soeharto said the Sharia Micro Finance Institution (LKMS) development is getting comprehensively well. At the moment there are 3,900 LKMS or BMT financing about 3 millions Indonesian micro and super micro entrepreneurs. Several of them have more than one service office. BMT condition socialization has massive nature added with high mobility factor calculation of the BMT administrator providing service outside the office "taking initiative". There is also other LKMS institution such as BPRS. Base on the Bank Indonesia statistics data there are 160 BPRS in September 2013 with 413 BPRS offices all over Indonesia.

Law No. 12013 article 12 explains that the activities of Micro Finance Institution (LKM) relate to financing or loan distribution and saving management by LKM may be operated as sharia principle and conventional. LKM activities in accordance with sharia principle should be carried out with sharia fatwa issued by the Dewan Syariah Nasional (DSN) - Majelis Ulama Indonesia (MUI), therefore the name should be Sharia Micro Finance Institution (LKMS). 
The purpose of micro finance institution (LKM and LKMS) is in accordance with Law No. 12013 Article 13, namely enhancing micro scale people funding access, helping enhance the economic empowerment and people productivity; and helping enhance people wealth and income especially poor and low income people. In accordance with the LKM/ LKMS purpose, the potential asset of the Sharia Micro Finance Institution was Rp 58.000.000.0000,-, belongs to BMT in 2006. The next year asset was Rp 695.000.000.000,- and then in 2008 and 2009 BMT asset has developed into 1.000.000.000.000.- and 1.600.000.000.000,- (Republika Online, 2012). The asset added with supporting resources in Indonesia is expected able to reduce geographic gap especially in economics due to state prosperity indicators detected from its economic growth.

The Sharia Micro Finance Institution strategic existence in enhancing low and middle people economic empowerment, especially at rural areas should always be fostered and maintained (Bin Mislan, 2010). Therefore it will become the best alternative to solve micro business problem especially in funding. The empowerment with products utility optimization and other financial services at the Sharia Micro Finance Institution is started with sustainable socialization with media and other ways therefore the LKMS will be known and benefitted by the people (Kasemsap, 2017).

Socialization is significant stage of the LKMS segmentation of low to middle people such as the people at Margoyoso-Pati District. The people at this level are constrained with several matters such as education level, perspective and lack of confidence to compete in business. In the end the micro business operators at this village successfully interact with LKMS. This opens widely the access to cooperate with LKMS to develop the business. Therefore, the local economy empowerment has been able to be enhanced. 
Margoyoso is a district at Pati regency, Central Java, province. The Margoyoso district consists of 22 villages. The LKMS amount in these 22 villages is lower compares to the total villages. There are only 4 (four) LKMS at Pati Regency, spread in several district such as BPRS Artha Mas Abadi, BMT Madani, BMT Fastabiq and BMT Yaumi Fatimah (Data Mitra LPDP-KUKM Provinsi Jawa Tengah, 2014). The effort to develop LKMS at Margoyoso-Pati District Central Java and other areas in Indonesia will need hard work from all related parties. The BMT/ LKMS operations should avoid the weaknesses. Those weaknesses are higher revenue sharing incriminating the administrator (mudharib), the administrator (mudharib) was not notified about the determined margin, and there was force confiscation on conflict solving. These weaknesses will create negative perception and reduce the quality. The perception could be reviewed from external perspective or people evaluation context.

According to Dian (2007), perception is the way human interpreting or sense processed collected information. Human perception is emerged from his/her own experience or other people impression. Accumulation of perception will establish an opinion, assumption or certain conclusion of his/ her experience. LKMS should operate comprehensively, namely in accordance with LKMS operational standard from its contracts, production names, and funding for the people. All of operations should follow sharia principles and also to introduce LKMS products. The LKMS should able to enhance administrator or staff quality (human resources) and enhancing quality service to its member and customers. It will affect LKMS performance and in creating people village positive perception.

This will need consistency, discipline, and cooperation of all related LKMS components. Therefore LKMS role, especially at Margoyoso Pati Village Central Java, on local economic empowerment will be relevant and effective. It is due to internally healthy LKMS practice, including 
customers, members, and other stakeholders. It also includes the external parties, namely people village positive perception using and not-using LKMS funding. Those internal and external practices will affect LKMS performance to enhance local economic at Margoyoso-Pati Village Central Java.

Sharia Micro Finance Institutions such as BMT, Sharia Financial Service Cooperation, or BPRS will indirectly enhance their growth due to people real need of those institutions. This need should be in accordance with LKMS better service to the people whereas from its human resources, management, or the efforts to erase BMT negative perception namely complicated and "loaning money to gain big profit." People positive perception will support people to joint LKMS and becoming member or customer to fulfill business or working modal or other consumptive needs. People are also able to get other financial services from LKMS such as saving or investment with sharia principles (LKMS products).

LKMS development will need people understanding enhancement on LKMS's products, mechanism, system, and details. LKMS development is depending on people demand on its system. Therefore, socialization activities for the people will be effective with information on motivation, perception, and LKMS customer/ debtor's decision. This research aims to answer of a question: how is rural community perception on Sharia Micro Finance Institution to empower local economics at Margoyoso-Pati District Central Java? Focus of this research is perception on LKMS using independent variables of LKMS products and services. The author argues that the two variables affect to rural community perception on LKMS to empower local economics. 


\section{Sharia Micro Finance and Service Quality}

Base on the Decision of Indonesia State Minister of Cooperation and Small to Middle Enterprises No.91/Kep/M.KUKM/IX/2004 on Application Guideline for Cooperation Enterprises Sharia Financial Services (JUKLAK KJKS). It explains the LKMS products and services, namely saving and deposits (wadia and mudharaba principles), providing funding services such as mudharaba, musharaka, murabaha, salam, istishna, and ijara; and also maal activities or budget collecting and distributing's activities of zakat, infaq, and shadaqo (ZIS) including wakaf.

All developed products and services of sharia micro financial institution are innovative and contributing low to middle people, for example funding in the form of working funding for small and middle entrepreneurs with profit sharing offering highly helpful in the business. The entrepreneurs do not need to pay in constant amount the interest to the investor; they only need to pay the profit sharing in accordance to the profit they get.

Service is evaluation or comprehensive attitude relate to the result of comparison between customer expectation and perception on previous service performance (Ariani, 2007). In order to fulfill customer satisfaction the service industry company such as banks, LKMS, hospitals and others need to manage good and qualified service. According to Tjiptono (2008) service quality definition is expected excellence level and excellence control to fulfill customer expectation. There are five service quality dimensions defined by Tjiptono (2008) namely SERVQUAL (Service Quality), namely Tangibles (physical evidence), Reliability (excellence), Responsiveness (responsiveness), Assurance (guarantee), and Empathy.

In order to operate Sharia Micro Financial Institution (LKMS) need to focus on their service quality to the people. Service quality is able to find with the comparison of consumer perception between the experienced 
service and the perceived service on LKMS service attributes. Whereas the customer of Sharia Micro Financial Institution (LKMS) considered their experienced service and perceived service is as expected therefore the service quality perception is good and satisfactory. The experienced service and perceived service is more than the expectation therefore the service quality perception is really good and satisfactory. In contrary whereas the experienced service and perceived service is less than the expectation therefore the service quality perception is bad.

\section{Perception Affecting Theories and Factors}

Personal perception emerges from the experiences from self or impression from other people. Perception accumulation will create opinion, assumption, or conclusion of the things experienced. Kotler (2000) stated that perception as personal process to select, manage, and interpret information inputs and creating meaningful comprehensive description. According to Simamora (2002), perception is how we see the world around us; for example there is an object, Matahari Store. The object, in fancy language, gives us stimulant. The stimulant provides as projection of Matahari Store therefore we may say, "I say the Matahari Store is exist and so on so forth."

The opinion shows perception as sensing process and accepted stimulants by a person with individual sensor then interpreted therefore able to be understood. The stimulant interpretation process is usually affected by individual learning process. The perception establishment process in a person is affected by various factors. Robbins (2001) stated the affecting factors of a person's perception establishment are at the perceiver side, the object, or the perceived target; or in the context whereas the perception is carried out. Those three factors are affecting of that one. The first factor is perception operator/ preceptor. A person sees an object and 
tries to interpret what he/ she saw. The interpretation will highly affected by personal characteristic of the perception operator.

The second is perception object/ target. Observed target's characteristics will affect object's perception. New thing, movement, sound, size, and other attributes of target will affect the way we observe it. The third is situation consists of time, situation or workplace, and social condition will affect our perception. As mentioned by Walgito (2002), the environment and special situation behind the stimulant will also affect perception, especially human as perception object. The explanation above shows the perception affecting factors is located in the perception creator, inside the meant object or target; or in the situation context whereas the perception was created.

\section{People Economic Empowerment}

People empowerment is economic development concept summarizing social values. This concept describe new development paradigm with the nature of people-centered, participatory, empowering, and sustainable (Zubaedi, 2013). People economic empowering is strengthening production ownership factors, strengthening distributing and marketing authority; strengthening people to gain proper salary or wages; and strengthening people to gain information, knowledge, and skill which should be done in multiple aspects in people aspect and policy aspect (Mardi, 2000). Therefore, the economic strategic issue has specific local nature and specific problem. People economic empowerment operational could not be formulated generally.

Formulating concept, approach, and the form of people economic empowerment operational in general is an important effort, however understanding the people powerlessness in economic sharing is much more important. It is due to clear understanding will make formulating 
concept, approach, and people economic empowerment operation form in accordance with local problem characteristic (Reisman, 2017). Local problem of the low level people is modal access. Financial business is always pushing people village; farmer, laborer, micro entrepreneur, small entrepreneur, and middle entrepreneur to increase their saving, whereas their need the funding from financial institution treats them discriminately.

It shows the modal flow is from lower level people to higher level people. Financial institution position is the mediator (Cervello-Royo, 2017). It is sharing the risk with borrowers, sharing information with borrower, and providing liquidity. The fact shows there are discriminative treatment to the lower level people and small entrepreneur on these three matters. The people do not have bargaining power on the injustice treatment on financial institution.

\section{Hypothesis Development}

The LKMS offers products in accordance with Islamic sharia principles, namely without interest and with profit sharing and buying selling. The profit sharing principle is the solution for the people, especially low to middle economic level people with significantly small modal. This principle will be more flexible due to no loss for each party, whereas profit will be share accordingly base on the nisbah, and whereas there is loss it also will be share accordingly.

Socialization program to the people would be significant in providing understanding on LKMS products. The products consist of guidance and operation, and also Operational and Procedure Standard (SOP) to carry out saving or funding activities and also other activities in accordance to sharia principle with more profit and merit than conventional LKM. 
More innovative, and more profitable LKMS products to the rural community has been better than conventional Micro Financial Institution (LKM), the rural community are expected give positive response on LKMS. Therefore, LKMS products will affect rural community perception of LKMS to empower local economy. Base on those matters the hypotheses are: H1: LKMS products have significant effect on rural community perception on Sharia Micro Financial Institution (LKMS).

The developing Sharia Micro Financial Institution (LKMS) needs to focus on service aspect to customer; over more LKMS is financial institution selling financial service products. The rapid and good (prime) service for customers or the people will make them satisfied. According to Tjiptono (2008) service quality definition is expected excellence level and control over the excellence level to fulfill customer expectation

Whereas there are customers of rural community satisfy with LKMS service, they are expected to provide positive response to LKMS. Therefore, LKMS services are able to affect the rural community perspective on Sharia Micro Financial Institution (LKMS) to empower local economy. Base on the right this hypothesis is arranged $\mathrm{H}_{2}$ : LKMS services have significant effect on rural community perception on Sharia Micro Financial Institution (LKMS).

Providing perspective or understanding and knowledge to rural community on LKMS products by offering them to rural community; and providing perspective or understanding and knowledge to rural community on services quality given by LKMS have similar purpose namely affect the rural community to response positively or give good perception to LKMS. Good or positive rural community perception will make whoever have budget surplus to save and manage it at LKMS in accordance with sharia principle. 
Rural community who needs fund or modal could directly visit LKMS and ask for funding with easier requirement and cheaper cost. They only have to pay the sharing profit from the profit they earned. Therefore the economics circle in the area is always moving with local economic empowerment due to production strengthening factor with the example modal easier access (Pianta, 2017).

Ariani (2007) shows that there is significant effect on significant and positive relation between service variable and community in general to Sharia Bank in Medan. She said the biggest contribution to perception on Sharia Bank in Medan is service variable. Suparno (2009) also shows average students $79.8 \%$ know the sharia banking products. The result shows economic faculty students of Syiah Kuala University have positive perception on sharia bank as sharia financial institution.

The explanation and the research founding will make this research testing LKMS products and services on rural community perception on Sharia Micro Financial Institution (LKMS) to empower local economy especially at Margoyoso-Pati District, Jawa Tengah. The hypothesis in this research is: $\mathrm{H}_{3}$ : LKMS products and services will simultaneously and significantly affect rural community perception on Sharia Micro Financial Institution (LKMS)

This research is carried out with survey. The data were primary data is the questionnaire answers from the respondents. The research design is explanatory research due to its explanation causal relation of the variables with hypothesis test (Adrianto, 2008). The causality design purpose is testing LKMS products and services effect on rural community perception on Sharia Micro Financial Institution (LKMS) to empower local economy.

The research is only limited with the problems of LKMS products and services in affecting rural community perception on Sharia Micro Financial Institution (LKMS) to empower local economy. The research 
population is the whole rural community around Margoyoso-Pati District Jawa Tengah consists of farmer, fishermen, entrepreneurs, and traders who have ever relation with LKMS and becoming LKMS member or customer, active or non-active. The sampling technique in used is sampling probability method. The sampling technique is carried out with simple random sampling.

The technique method in used in hypothesis test is multiple regressions. The analysis in used to test LKMS products and services effect on rural community perception on Sharia Micro Financial Institution (LKMS) to empower local economy is data analysis model shown below:

First, testing LKMS products with significant effect on rural community perception on Sharia Micro Financial Institution (LKMS) (hypothesis 1)

Equation: $Y=\beta_{0}+\beta_{1} X_{1}+e$

Second, testing LKMS services with significant effect on rural community perception on Sharia Micro Financial Institution (LKMS) (hypothesis 2).

Equation: $Y=\beta_{0}+\beta_{2} X_{2}+e$

Third, testing LKMS products and services with significant and simultaneous effect on rural community perception on Sharia Micro Financial Institution (LKMS) (hypothesis 3).

Equation: $Y=\beta_{0}+\beta_{1} X_{1}+\beta_{2} X_{2}+e$

Explanation:

$\begin{array}{lll}\mathrm{Y} & = & \text { Rural Community Perception on LKMS } \\ \mathrm{X}_{1}= & \text { LKMS Products } \\ \mathrm{X}_{2}= & \text { LKMS Services } \\ \beta_{0}= & \text { Constance/ Intercept } \\ \beta_{1-4}= & \text { Regression Coefficient } \\ \mathrm{e}= & \text { Error Standard }\end{array}$


The hypothesis test truth evidence is gained with statistic testing on the output of regression equation. The statistic testing in used are $\mathrm{R}^{2}$ Test (determinant coefficient) to measure the model ability in explaining independent variable variation, Individual Parameter Significant Test ( $T$ Statistic Test) with significant level in used $5 \%$ or 0.05 (Two Sides Test), Simultaneous Significant Test (F Statistic Test) with Significant level in used $5 \%$ or 0.05 (Two Sides Test).

Validity test in used is Pearson Correlation Test, namely score correlating test earned of each question item with total scores of each construct (Ghozali, 2005). The test is using two sides test with significant level 0.05. The test criteria, with $r_{\text {calculation }}>r_{\text {table }}(2$ sides test with sig. 0.05) therefore the instrument or question items have significant correlation on total score (considered valid). However with $r_{\text {calculation }}<r_{\text {table }}$ (2 sides test with sig. 0.05$)$ therefore the instrument or question items do not have significant correlation on total score (considered not valid). The researcher was carried the reliability test using Cronbach's Alpha of each instrument in the variable. The instrument in used is considered reliable whereas Cronbach's Alpha is bigger than 0.60 (Ghozali, 2005). The researcher was testing classic assumption consists of normal test, multicollinearity, and heteroscedasticity before testing the hypothesis with multiple regression analysis.

\section{General Sample Description}

This research was carried out at Margoyoso District area consists of 22 villages. The area was chosen due to its population majority is farmer, fisherman, traders/ entrepreneur, and laborer; and also its lack of Sharia Micro Financial Institution (LKMS). The area needs LKMS development and enhancement to empower local economy for example the empowerment in farming, plantation, fishery, and crafting. 
The field survey by the researcher in August 2015 shows from 22 villages there were 5 Sharia Micro Financial Institution (LKMS) operated. Those are PT. BPRS Artha Mas Abadi, Jl. Raya Pati Tayu KM. 19, Waturoyo, Margoyoso-Pati; Koperasi Jasa Keuangan Syariah (KJKS) BMT Madani, Jl. Ronggo Kusumo, Ngemplak Kidul Rt 06/04, Margoyoso - Pati; Koperasi Jasa Keuangan Syariah (KJKS) BMT Fastabiq Cabang Mragoyoso, Jl. Raya Juwana-Tayu, Margoyoso - Pati; Koperasi Simpan Pinjam Syariah (KSPS) BMT Usaha Syariah Bersama Jl. Raya Pati Tayu KM 20, Purworejo, Margoyoso - Pati; and BMT Yaummi Fatimah Cabang Margoyoso, Jl. Ampera No. 03 Bulumanis, Margoyoso - Pati.

The respondents of this research consist of the whole rural community around Margoyoso area who has ever related to LKMS as member or customer, active or non-active.

Table 1

Research Data Sample

\begin{tabular}{|c|l|c|c|}
\hline No & \multicolumn{1}{|c|}{ Explanation } & Amount & Percentage \\
\hline 1 & Delivered questionnaires & 150 & $100 \%$ \\
\hline 2 & Unreturned questionnaires & 8 & $5,3 \%$ \\
\hline 3 & Unprocessed questionnaires & 6 & $4,0 \%$ \\
\hline 4 & Processed questionnaires & 136 & $90,7 \%$ \\
\hline
\end{tabular}

Source: Processed primary data

There are 150 questionnaires delivered to the respondents. The returned questionnaires are 136 or $90.7 \%$. The unreturned ones are 8 or $5.3 \%$ due to missing or un-responded. The unprocessed questionnaires are due to incompletely filled by respondents are 6 or $4 \%$. Validity test result shows the instruments of LKMS products, services, and rural community perception have valid criteria on question item with significant value smaller than 0.05 and $r_{\text {calculation }}$ value bigger than $r_{\text {tabel }}$ (two sides test with sig. 0.0.5). 
The reliability test result shows the reliable result for three research variables use in this research:

Table 2

Reliability Test Result

\begin{tabular}{|l|c|c|}
\hline \multicolumn{1}{|c|}{ Variable } & Cronbach's Alpha & Explanation \\
\hline $\begin{array}{l}\text { LKMS Rural } \\
\text { Community Perception }\end{array}$ & 0,772 & Reliable \\
\hline LKMS Products & 0,757 & Reliable \\
\hline LKMS Services & 0,749 & Reliable \\
\hline
\end{tabular}

Source: processed primary data

Table 2 shows Cronbach's Alpha value on rural community perception variable on LKMS is 0.772 , on LKMS products is 0.757 , and LKMS services is 0.749 . The conclusion is the statement on the questionnaire is reliable due the Cronbach's Alpha value bigger than 0.6. It shows each question item in used will provide consistent data, meaning whereas the question asked again the answer will be relatively similar.

\section{Classical Assumption Test Result}

The normal test result using One Simple Kolmogorov-Smirnov method shows asymp.sig.(2-tilled) value is 0.518 bigger than 0.005 . It means the residual are distributed normally (Ghozali, 2005). The normality test result shows on Table 3.

Table 3

Normal Statistic Test Result

\begin{tabular}{|ll|r|}
\hline One-Sample Kolmogorov-Smirnov Test & Un-standardized Residual \\
\hline $\mathrm{N}$ & Mean & 136 \\
Normal Parameters ${ }^{\mathrm{a}, \mathrm{b}}$ & Std. Deviation & .0000000 \\
& Absolute & 2.76633910 \\
& .070 \\
Most Extreme Differences & Positive & .070 \\
& Negative & -.036 \\
Kolmogorov-Smirnov Z & & .817 \\
Asymp. Sig. (2-tailed) & & .518 \\
\hline
\end{tabular}

Vol. 2 No. 1, January - April 2017 
a. Test distribution is Normal.

b. Calculated from data.

Source: Processed Primary Data

The result is consistence with P-Plot Graphic and Histogram Graphic previously tested. The P-Plot Graphic output shows the spreading dots around diagonal line and the spreading following diagonal line. The Histogram output shows the created tabulation is following diagonal line. The curve line expands to the same side on the left and right of the histogram. It means the data distribution is normal. Therefore the normal test result shows regression model fulfilled the normal assumption.

Table 4

Multicollinearity Test Result

Coefficients $^{\mathrm{a}}$

\begin{tabular}{|c|c|c|c|c|c|c|c|c|}
\hline & \multirow{2}{*}{ Model } & \multicolumn{2}{|c|}{$\begin{array}{l}\text { Unstandardized } \\
\text { Coefficients }\end{array}$} & \multirow{2}{*}{$\begin{array}{c}\text { Standardized } \\
\text { Coefficients }\end{array}$} & \multirow{2}{*}{$\mathrm{t}$} & \multirow{2}{*}{ Sig. } & \multicolumn{2}{|c|}{ Collinearity Statistics } \\
\hline & & B & Std. Error & & & & Tolerance & VIF \\
\hline 1 & (Constant) & -2.629 & 2.990 & & -.879 & .381 & & \\
\hline & LKMS Products & .823 & .089 & .590 & 9.211 & .000 & .964 & 1.038 \\
\hline & LKMS Services & .346 & .085 & .262 & 4.087 & .000 & .964 & 1.038 \\
\hline
\end{tabular}

a. Dependent Variable: Rural community perception LKMS Source: Processed Primary Data

The table 4 shows each variable has tolerance value is $<0.10$ variance inflation factor (VIF) value $>10$. The multicollinearity test result shows VIF value of LKMS products and services is 1.038 each. The tolerance value for the variables of LKSM products and services is 0.964 each. The test result indicates there is no multicollinearity problem between independent variables on the regression model used in this research.

The heteroscedasticity test result shows the dots spread randomly and does not create certain pattern, above and below the 0 number of $Y$ axle. It shows there is no heteroscedasticity on regression model. It means 
regression model is not proper to predicts rural community perception on LKMS base on the affecting factors, namely the LKMS products and services. The heteroscedasticity is shown on picture 1 :

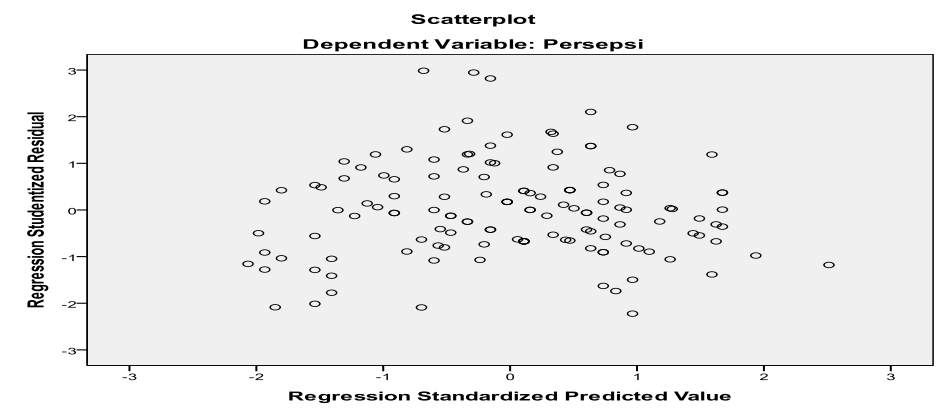

\section{Picture 1: Heteroscedasticity Test Result}

Source: Processed primary data

\section{Hypothetical Test}

The first hypothesis was testing LKMS products $\left(\mathrm{X}_{1}\right)$ significant effect on rural community perception on Sharia Micro Financial Institution (LKMS). The test is carried out using simple linear regression with determinant coefficient test and $\mathrm{t}$ statistic test. The $\mathrm{R}$ value test result, base on table 5 , is 0.639 correlation number meaning the relation of variables independent and dependent is strong. The positive correlation shows one way relation, meaning the better rural community understanding on LKMS products, the better their perception on LKMS. The R Square $\left(\mathrm{R}^{2}\right)$ value on table 5 shows LKMS products variable are able to explain rural community perception variable on LKMS. The rest $59.1 \%$ is explained by other things outside the models. 
Table 5

Hypothesis 1 Determinant Coefficient Test Result

Model Summary

\begin{tabular}{|l|r|r|r|r|}
\hline Model & R & R Square & $\begin{array}{c}\text { Adjusted R } \\
\text { Square }\end{array}$ & $\begin{array}{c}\text { Std. Error of the } \\
\text { Estimate }\end{array}$ \\
\hline 1 & $.639^{a}$ & .409 & .404 & 2.946 \\
\hline
\end{tabular}

a. Predictors: (Constant), LKMS Products

b. Dependent Variable: Rural community perception on LKMS

Source: Processed primary data

Table 6 shows $t_{\text {calculation }}$ result is 9.627 at significant level 0.000 meaning smaller than 0.05 . It means the test LKMS products individually have significant effect on rural community perception on LKMS. It shows support for $\mathrm{Ha}_{1}$ statement LKMS products $\left(\mathrm{X}_{1}\right)$ has significant effect on rural community perception on Sharia Micro Financial Institution (LKMS) and rejecting $\mathrm{H}_{1}$. The research result is in consistency with the BMT is good and has real effect on local economy business function with contract (products) funding to develop the business.

Table 6

\section{Hypothesis 1 t Statistic Test Result}

Coefficients $^{\mathrm{a}}$

\begin{tabular}{|c|c|c|c|c|c|c|}
\hline \multirow{2}{*}{\multicolumn{2}{|c|}{ Model }} & \multicolumn{2}{|c|}{$\begin{array}{l}\text { Unstandardized } \\
\text { Coefficients }\end{array}$} & \multirow{2}{*}{$\begin{array}{c}\text { Standardized } \\
\text { Coefficients } \\
\text { Beta }\end{array}$} & \multirow{2}{*}{$\mathrm{t}$} & \multirow{2}{*}{ Sig. } \\
\hline & & B & Std. Error & & & \\
\hline \multirow[b]{2}{*}{1} & (Constant) & 5.876 & 2.269 & & 2.590 & .011 \\
\hline & $\begin{array}{l}\text { LKMS } \\
\text { Products }\end{array}$ & .893 & .093 & .639 & 9.627 & .000 \\
\hline
\end{tabular}

a. Dependent Variable: Rural community perception on LKMS Source: Processed primary data

The second hypothesis tested LKMS services $\left(\mathrm{X}_{2}\right)$ have significant effect on rural community perception on Sharia Micro Financial Institution (LKMS). The test was using simple linear regression with determinant 
coefficient test and statistic test. The $\mathrm{R}$ value calculation base on table 7 shows correlation number of 0.374 meaning the relation of independent and dependent variables are low. Positive correlation shows one way relation meaning the better rural community understanding on LKMS services, the better their perception on LKMS.

\section{Table 7}

\section{Hypothesis 2 Determinant Coefficient Test Result Model Summary}

\begin{tabular}{|l|c|r|r|c|}
\hline Model & $\mathrm{R}$ & R Square & $\begin{array}{c}\text { Adjusted R } \\
\text { Square }\end{array}$ & $\begin{array}{l}\text { Std. Error of the } \\
\text { Estimate }\end{array}$ \\
\hline 1 & $.374^{\mathrm{a}}$ & .140 & .133 & 3.554 \\
\hline
\end{tabular}

a. Predictors: (Constant), Services

b. Dependent Variable: Rural community perception on LKMS Source: Processed Primary Data

The $\mathrm{R}$ Square $\left(\mathrm{R}_{2}\right)$ value table 7 shows budget arrangement participation variable is able to explain $14.0 \%$ LKMS services variable. The rest 89.0 is caused by other things outside model.

Table 8

\section{Hypothesis 2 t Statistic Test Result}

Coefficients $^{\mathrm{a}}$

\begin{tabular}{|c|c|c|c|c|c|c|}
\hline \multirow{2}{*}{\multicolumn{2}{|c|}{ Model }} & \multicolumn{2}{|c|}{$\begin{array}{c}\text { Unstandardized } \\
\text { Coefficients }\end{array}$} & \multirow{3}{*}{$\begin{array}{c}\text { Standardized } \\
\text { Coefficients }\end{array}$} & \multirow{3}{*}{$\begin{array}{c}\mathrm{t} \\
4.146 \\
\end{array}$} & \multirow{3}{*}{$\begin{array}{l}\text { Sig. } \\
.000 \\
\end{array}$} \\
\hline & & \multirow{2}{*}{$\frac{B}{13.007}$} & \multirow{2}{*}{$\begin{array}{r}\text { Std. Error } \\
3.138 \\
\end{array}$} & & & \\
\hline & (Constant) & & & & & \\
\hline 1 & \begin{tabular}{|l|} 
LKMS \\
Services
\end{tabular} & .495 & .106 & .374 & 4.667 & .000 \\
\hline
\end{tabular}

a. Dependent Variable: Rural community perception on LKMS Source: Processed primary data 
The $\mathrm{t}_{\text {calculation }}$ value result of table 8 on LKMS services variable is 4.667 at significant level of 0.000 , smaller than 0.05 . The $t$ test shows LKMS services individually have significant effect on rural community perception on LKMS. The result was supporting Ha. ${ }_{2}$ statement LKMS services have significant effect on rural community perception on Sharia Micro Financial Institution (LKMS) and rejecting $\mathrm{H} 0_{{ }_{2}}$. The research is at consistency with the research of Dian Ariani (2007) stated service variable was providing the biggest contribution on general community perception on sharia financial community (sharia banking).

The third hypothesis is LKMS products and services have simultaneous and significant effect on rural community perception on Sharia Micro Financial Institution (LKMS). The third hypothesis was carried out with multiple linear regression with determinant coefficient test and F statistic test (Anova) and t statistic test. Table 9,10, and 11 shows Determinant Coefficient Test, F Statistic Test (Anova), and hypothesis $3 \mathrm{t}$ Statistic Test are:

\section{Table 9}

\section{Hypothesis 3 Determinant Coefficient Test Result Model Summary}

\begin{tabular}{|l|c|r|r|r|r|}
\hline Model & R & R Square & \multicolumn{1}{|c|}{$\begin{array}{c}\text { Adjusted R } \\
\text { Square }\end{array}$} & $\begin{array}{c}\text { Std. Error of } \\
\text { the Estimate }\end{array}$ & $\begin{array}{l}\text { Durbin- } \\
\text { Watson }\end{array}$ \\
\hline 1 & $.689^{\mathrm{a}}$ & .475 & .467 & 2.787 & 1.218 \\
\hline
\end{tabular}

a. Predictors: (Constant), LKMS Services, LKMS Products b. Dependent Variable: Rural community perception on LKMS Source: Processed primary data

$\mathrm{R}$ value result base on table 9 is correlation number of 0.689 meaning the relation of dependent and independent variables is strong. The positive correlation shows one way relation meaning the better rural community understanding on LKMS products and products quality, the 
better their perception on LKMS. The Adjusted R Square (Adjusted R²) on table 9 shows LKMS products and services variables explaining $46.7 \%$ variable of rural community perception on LKMS. The rest $53.3 \%$ are explained by other things outside the model.

Table 10

\section{Hypothesis 3 F Statistic Test Result}

ANOVA $^{b}$

\begin{tabular}{|l|l|r|r|r|c|c|}
\hline \multicolumn{2}{|c|}{ Model } & Sum of Squares & \multicolumn{1}{c|}{ df } & Mean Square & F & Sig. \\
\hline \multirow{3}{*}{1} & Regression & 934.005 & 2 & 467.002 & 60.121 & $.000^{a}$ \\
\cline { 2 - 7 } & Residual & 1033.105 & 133 & 7.768 & & \\
\cline { 2 - 7 } & Total & 1967.110 & 135 & & & \\
\hline
\end{tabular}

a. Predictors: (Constant), LKMS Services, LKMS Products

b. Dependent Variable: Rural community perception on LKMS Source: Processed primary data

F test result on the table is 4.27 meaning the significance value (probability) 0.0000 smaller than 0.05 . It indicates Hypothesis $3\left(\mathrm{Ha}_{3}\right)$ is accepted. The LKMS products and services are simultaneously and significantly have significant effect on rural community perception on Sharia Micro Financial Institution (LKMS) proven real meaning this research is rejecting $\mathrm{H}_{03}$.

The $t$ statistic test for LKMS products variable $\left(\mathrm{X}_{1}\right)$ dan LKMS services $\left(\mathrm{X}_{2}\right)$ effect on rural community perception on Sharia Micro Financial Institution (LKMS) (Y).

Table 11

\section{Hypothesis 3 t Statistic Test Result} Coefficients $^{\mathrm{a}}$

\begin{tabular}{|l|l|l|l|l|l|l|}
\hline \multicolumn{2}{|l|}{ Model } & \multicolumn{2}{|l|}{$\begin{array}{l}\text { Unstandardized } \\
\text { Coefficients }\end{array}$} & $\begin{array}{l}\text { Standardized } \\
\text { Coefficients }\end{array}$ & $\mathrm{t}$ & Sig. \\
\cline { 3 - 7 } & & B & Std. Error & Beta & & .381 \\
\hline 1 & (Constant) & -2.629 & 2.990 & & -.879 & .000 \\
\hline
\end{tabular}




\begin{tabular}{|l|l|l|l|l|l|l|}
\hline $\begin{array}{l}\text { LKMS } \\
\text { Products }\end{array}$ & .823 & .089 & .590 & 9.211 & .000 \\
\hline & LKMS Services & .346 & .085 & .262 & 4.087 & \\
\hline
\end{tabular}

The table 11 shows $\mathrm{t}_{\text {calculation }}$ value result on LKMS products variable is 9.211 at significant level 0.000 smaller than 0.05 . The conclusion of $t$ test is LKMS products individually have significant effect rural community perception on LKMS. The $\mathrm{t}_{\text {calculation }}$ value on LKMS services variable is 4.087 at significant level 0.000 meaning significant due to its smaller value than 0.05 . The $t$ test result conclusion is LKMS services have significant effect on rural community perception of LKMS.

The research result is supporting Hypothesis $\mathrm{Ha}_{3}$ stated LKMS products and services have simultaneous and significant effect on rural community perception on Sharia Micro Financial Institution (LKMS) and rejecting $\mathrm{HO}_{3}$. It means LKMS products and services variables individually is the combination of two good independent variables and able to enhance rural community perception on LKMS.

The research result is in consistency with previous research by Eka Adi Nugroho (2013) and Suparno (2009) mentioning Sharia Financial Institution (BMT/ Sharia Bank) products have good (positive) perception on Sharia Financial Institution (BMT/ Sharia Bank). It was also applied on LKMS services according to Dian Arini (2009) stated the services of sharia financial institution (sharia bank) has provided biggest contribution to the sharia financial institution (sharia bank).

The explanation above shows there are rural community good and positive perceptions on rural community. Therefore the rural community with surplus budget could entrust it to be saved and managed at the LKMS in accordance with sharia principles. It is likewise for the rural community need fund or modal they could go directly to LKMS to gain funding with 
easier requirement and cheaper cost, they only have to pay profit sharing in accordance to the earned profit.

The economical wheel at certain area will always move with local economy empowerment with production strengthening factor such as modal easy access. Modal at present time is significant problem to the low (small) economy level people due to the access on the modal. The rural community of famer, laborer, micro traders, small trader, and middle trader, in money business, are always supported to enhance their saving. Whereas they need modal they are treated discriminatively by financial institution due many requirements to be fulfilled. Therefore the LKMS was emerged to fulfill the rural community need in order to empower local economy of the rural economy with sharia system as mentioned by the LKMS purposes at JUKLAK KJKS 2004 Article 2.

\section{Conclusion}

This research supports the first hypothesis $\mathrm{Ha}_{._{1}}$ and rejecting H0. stated LKMS products have significant effect on rural community perception on Sharia Micro Financial Institution (LKMS). It means the better rural community understanding and knowledge on LKMS products, the better their perception on LKMS to empower local economics. This research also supports the first hypothesis $\mathrm{Ha}_{2}$ and rejecting $\mathrm{H}_{0} ._{2}$ stated LKMS services have significant effect on rural community perception on Sharia Micro Financial Institution (LKMS). It means the better rural community understanding and knowledge on LKMS services quality, the better their perception on LKMS to empower local economics.

This research supports the first hypothesis $\mathrm{Ha}_{3}$ and rejects $\mathrm{H} 0 ._{3}$ stated LKMS products and services have significant and simultaneous effect on rural community perception on Sharia Micro Financial Institution (LKMS). It means the better rural community understanding 
and knowledge on LKMS offered products and quality services; these two variables able to affect rural community perception on LKMS to empower local economics.

\section{References}

Bin Mislan Cokro Hadisumarto, W., Ghafar, A. (2010). Improving the Effectiveness of Islamic Micro-Financing: Learning from BMT Experience. Humanomics 26 (1), pp. 65-75.

Cervello-Royyo, R., Guijarro, F., Martinez-Gomez, V. (2017). Social Performance Considered within the Global Performance of Microfinance Institutions: A New Approach. Operational Research, pp. 1-9.

Farid, Apit. (2015). "Eksistensi Lembaga Keuangan Mikro Syariah Dalam memberdayakan Ekonomi Masyarakat Kecil Menengab”, makalah Hakim Pengadilan Agama Sangeti, diakses melalui website 23 April 2015

Data Mitra. (2014). LPDB-KUMKM Per 31 Desember 2014 Dinas Koperasi Di Provinsi - Jawa Tengah

Ariani, Dian. (2007). "Persepsi Masyarakat Umum Terhadap Perbankan Syariah di Medan "Tesis Sekolah Pasca Sarjana Universitas Sumatera Utara, Medan, 2007.

Eka A. N. (2013). "Persepsi Masyarakat Terhadap Baitul Maal Wat Tamwil (BMT) dalam pemberdayaan ekonomi lokal (Studi pada BMT MUU Sidogiri Pasuruan) "Skripsi Fakultas Ekonomi dan Bisnis, Universitas Brawijaya.

Fandy, Tjiptono. (2008). "Strategi Pemasaran” Edisi Ketiga, Andi, Yogyakarta.

Ghozali, I. (2005). Analisis Multivariate dengan Program SPSS” Penerbit 
Universitas Diponegoro, Semarang

Gibson, dkk. (1997). Organisasi (Perilaku, Stuktur, Proses). Jild I, Edisi ke 8 (Alih Bahasa : Nunuk Adriani). Jakarta, Bina Rupa Aksara.

http:/www.pendidikanekonomi.com/2012/12/pemberdayaan-ekonomimasyarakat.html, accessed March 24, 2015

http://www.puskopsyahlampung.com/2013/05/perkembangan-bmt-daritahun-ke-tahun.html accessed October 23, 2015

h t t p : / / www.republika.co.id/berita/bis nis-syariah / berita/10/04/21/112221-bmt-center-salurkan-pembiayaan-rp-3triliun accessed April 1, 2015

http://www.republika.co.id/berita/ekonomi/syariah-ekonomi/15/03/22/ nlmhlb-aset-bmt-indonesia-capai-rp-47-triliun accessed October 25, 2015

Kamus Bahasa Indonesia. Ensiklopedi Bahasa Indonesia (2001) Jakarta: KBI, (2001).

Kasemsap, K. (2017). Exploring the Role of Microfinance in Emerging Nations. Financial Entrepreneurship for Economic Growth in Emerging Nations, pp. 174-193.

Katalog BPS dan BAPPEDA Kabupaten Pati, Kecamatan Margoyoso dalam angka, (2006).

Kementerian Koperasi dan UKM, Petunjuk Pelaksanaan Kegiatan Usaha Koperasi Jasa Keuangan Syariah, Jakarta, (2005).

Kotler, P. (2004). Marketing Management Analyisis, Planning, Implementation and Control Edition, New Jersey : Prentice Hall Inc.

Mardi Yatmo Hutomo, SU adalah staf pengajar pada Fakultas Pertanian Universitas Wangsamanggala Yogyakarta. Pokok-pokok pikiran dalam tulisan ini pernah disampaikan pada Seminar Sehari Pemberdayaan Masyarakat yang diselenggarakan Bappenas, tanggal 6 Maret 2000 di Jakarta.

Pianta, M. (2017). Innovation and Economic Change. Economics of 
Innovation and New Technology 26 (8), pp. 683-688.

Reisman, E. (2017). Troubling Tradition, Community, and Self-Reliance: Reframing Expectations for Village Seed Banks. World Development 98, pp. 160-168.

Ringkasan Penelitian BI bekerjasama dengan Universitas Dipenogoro, 2000, Penelitian Potensi, Preferensi dan Perilaku Masyarakat terhadap Bank Syariah di Wilayah Jawa Tengah dan Daerah Istimewa Yogyakarta. Semarang.

Robbins, S. P. (2002). “Perilaku Organisasi” Jilid I, Pearson Education Asia Pte.Ltd dan PT. Prenhallindo, Jakarta.

Simamora, H. (2002). “Manajemen Sumber Daya Manusia”, Edisi ketiga, Cetakan Pertama, Penerbit STIE YKPN, 2002

Sugiyono. (2009). Metodologi Penelitian Bisnis Edisi13, Penerbit CV. Alfabeta, Bandung.

Suparno (2009). "Persepsi mahasiswa fakultas ekonomi universitas syiah kuala terhadap perbankan syariah sebagai lembaga keuangan syariah" Jurnal Telaah \& Riset Akuntansi. 2 (1). Januari. pp. 93-103

Sutopo, HB. (2006). Metode Penelitian Kualitatif. Surakarta, UNS Press. Uma Sekaran. (2006). Metodologi Penelitian untuk Bisnis. Salemba Empat, Jakarta.

Undang-undang Republik Indonesia No. 13 Tahun 2013 tentang Lembaga Keuangan Mikro, disahkan (Presiden Bambang Yudhoyono) dan diundangkan (Menteri Hukum dan Hak Asasi Manusia RI) paa tanggal 8 Januari 2013, Bagian Penjelasan.

Undang-undang Republik Indonesia No. 25 Tahun 1992 tentang Perkoperasian, disahkan (Presiden Soeharto) dan diundangkan (Sekertariat Jenderal Moerdiono) paa tanggal 21 Oktober 1992, Bagian Penjelasan.

Walgito, B. (2002). “Pengantar Psikologi Umum”, Andi Offset, Yogyakarta. 


\section{Shirkah Author Guidelines}

Shirkah currently offers two routes to submit manuscripts. We highly recommend to submit the articles which are made using OJS (Open Journal System). Feel free register as author soon through visiting http:// shirkah.or.id/index.php/home/user/register. The authors may directly send their manuscripts, along with their resume, to shirkahiainsurakarta@ gmail.com. Please prepare your manuscripts, using following guidelines:

1. Manuscript must be written in English. Submitted articles should not have been published or be under review for publication with another journal.

2. Manuscript's length is about $15-20$ pages, typed in one-half spaced on A4-paper size.

3. Manuscript must include an $150-200$ word abstract and keywords.

4. Manuscript must be arranged as follows: Title, Name of Author, E-mail address, Abstract, Keywords, Introduction (including method if any), Discussion, Conclusion, References.

5. Manuscript's titles not more than ten words.

6. Manuscript must be submitted in Microsoft Word or RTF.

7. Arabic words should be transliterated according to the style of International Journal of Middle Eastern Studies.

8. Manuscript references are preferably derived from the up-to-date references.

9. The author's resume should be submitted separately, consisting of at least full name, institutional address, phone number, areas of studies, and recent publications (if any).

10. Shirkab use APA Style 6th edition (2010) as reference format writing. We suggest the use of a reference manager software such as Mendeley, Zotero, and Endnote at templating the citation style. APA Style to be used is as follows: 


\section{Book with single author}

Swann, G. M. Peter. (2014). The Economics of Innovation an Introduction. Cheltenhum \& Northampton: Edward Elgar.

in-text citation: (Swann, 2014)

\section{Articles in reference books}

Alatas, S. F. (2006). Islam and the Science of Economics in Abu Rabi', I.M. The Blackwell Companion to Contemporary Islamic Thought. USA: Willey-Blackwell (pp. 587-606).

in text citation: (Alatas, 2006)

\section{E-Book}

Hackett, Rosalind (2007). "Religous Dimentions of War and Peace: Introduction.” Dalam Gerrie ter Haar dan Yoshio Tsuruoka (Ed.), Religion and Society: An Agenda for the 21st Century (h. 3-6). Retrieved from http:// brill.nl.

in text citation: (Hackett, 2006)

\section{Master's thesis, from a commercial database}

McNieI, D. S. (2006). Meaning through narrative: A personal narrative discussing growing up with an alcoholic mother (Master's thesis). Available from ProQuest Dissertations and Theses database. (UMI No. 1434728)

in text citation: (Mc Niel, 2006)

\section{Doctoral dissertation, from an institutional database}

Adams, R. J. (1973). Building a foundation for evaluation of instruction in higher education and continuing education (Doctoral dissertation). Retrieved from http://www.ohiolink.edu/etd/

in text citation: (Adams, 1973) 


\section{Doctoral dissertation, from the web}

Bruckman, A. (1997). MOOSE Crossing: Construction, community, and learning in a networked virtual world for kids (Doctoral dissertation, Massachusetts Institute of Technology). Retrieved from http:/www-static. cc.gatech.edu/--asb/thesis/ in text citation: (Bruckman, 1997)

\section{Journal article with No DOI}

Bourkhis, K., and Nabi, M. S. (2013). Islamic and conventional banks' soundness during the 2007-2008 financial crisis. Journal Metrics, 22(2), 68-77.

in-text citation: (Bourkhis \& Nabi, 2013).

\section{Journal article with DOI}

Ichwan, M. (2012). The Local Politics Of Orthodoxy: The Majelis Ulama Indonesia in the Post-New Order Banten. Journal Of Indonesian Islam, 6(1), 166-194. doi:http://dx.doi.org/10.15642/JIIS.2012.6.1.166-194

In text citation : (Ichwan, 2012)

\section{Abstract as citation}

Hasan, N. (2012). Islamist Party, Electoral Politics And Da'wah Mobilization Among Youth : The Prosperous Justice Party (PKS) in Indonesia. Journal of Indonesian Islam, 6(1), 17-47. Abstract from http:// jiis.uinsby.ac.id/index.php/jiis/article/view/97

in text citation : (Hasan, 2012)

\section{Mass media article}

Sahal, Akhmad (2014, March 2). Kiai Sahal dan Realisme Fikih.Tempo Magazine, p. 120.

in text citation : (Sahal, 2014) 


\section{Research report}

Fisher, B. S., Cullen, F. T., \& Turner, M. G. (2000). The Sexual Victimization of College Women. Research Report.

in text citation : (Fisher, Cullen, Turner, 2000)

\section{Monograph}

Routray, Bibhu Prasad (2013), National Security Decision-Making in India (RSIS Monograph No. 27). Singapura: Rajaratnam School of International Studies.

in text citation : (Routray, 2013)

\section{Proceeding article}

Sudibyakto, Hizbaron, D.R., \& Jati, R (Ed.) (2009), Proceeding International Seminar Disaster Theory, Research and Policy. International seminar held by Sekolah Pascasarjana, Universitas Gajahmada, Yogyakarta, 8-9 Desember 2009.

in text citation : (sudibyakto and Jati, 2009)

\section{Paper conference/seminar/symposium}

Janutama, Herman Sinung (2011). "Kraton dan Hubungan Antar Agama." Paper presented in Seminar Kraton dan Panatagama held by Center for the Study of Islam and Social Transformation (CISForm), Yogyakarta, 17 November.

in text citation :(Janutama, 2011)

\section{Online article in web}

Shiva, (2006, February). Bioethics: A Third World Issue. Native-web. Diperoleh dari http://www.nativeweb.org/ pages/legal/shiva.html

in text citation : (Shiva, 2006) 


\section{Online research report}

Kessy, S. S. A., \& Urio, F M. (2006). The contribution of microfinance institutions to poverty reduction in Tanzania (Research Report No. 06.3). Retrieved from Research on Poverty Alleviation website: http://www. repoa.or.tz /documents_storage/Publications/Reports/06.3_Kessy_and_ Urio.pcif

in text citation : (kessy and urion, 2006)

\section{Holy book}

Qur an, $2(25)$

In text citation : (Q. al-Baqarah 2:25).

\section{Encyclopaedia}

Graycar, Adam (1992). Social Welfare Policy. Dalam Mary Hawkesworth dan Maurice Kogan (Ed.), Encyclopedia of Government and Politics (Vol. 1). London: Routledge.

in text citation : (Graycar, 1992)

\section{Interview}

Sultan Hamengkubuwono X (interview, 2011, April 19)

in text citation: (Hamengkubuwono, 2011)

\section{Documentary film}

Steijlen, Fridus (2008). A Day in the Life of Indonesia [documentary film, 58 minutes]. Leiden: KITLV Press.

in text citation : (Steijlen, 2008) 
Vol. 2 No. 1, January - April 2017 